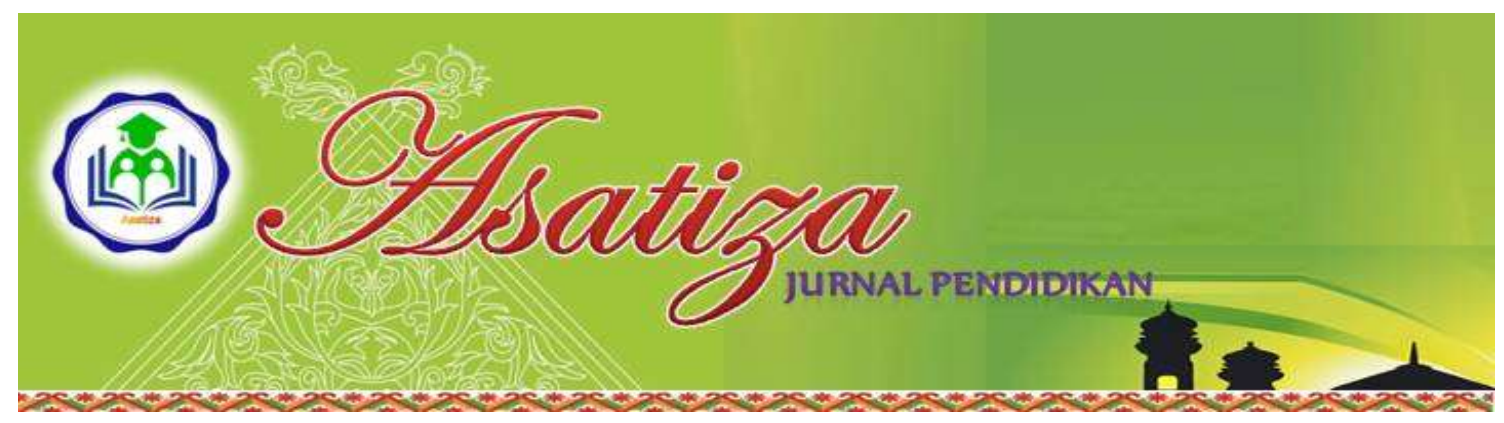

\title{
PENGARUH MOTIVASI GURU TERHADAP AKTIVITAS BELAJAR SISWA KELAS TINGGI DI MADRASAH IBTIDAIYAH PONDOK PESANTREN AL-RASYID SIMPANG JAYA KECAMATAN BATANG TUAKA \\ Yona Lisa Putri ${ }^{1}$
}

\author{
${ }^{1}$ Mahasiswi Prodi PAI STAI Auliurrasyidin Tembilahan, Indonesia
}

\begin{abstract}
Abstrak
Tujuan dalam penelitian ini mencari pengaruh motivasi guru terhadap aktivitas belajar siswa kelas tinggi di Madrasah Ibtidaiyah Pondok Pesantren Al-Rasyid Simpang Jaya Kecamatan Batang Tuaka. Populasi dalam penelitian ini adalah 4 orang guru dan 132 orang siswa di Madrasah Ibtidaiyah Pondok Pesantren Al-Rasyid Simpang Jaya Kecamatan Batang Tuaka. Sampel untuk guru tidak ada, dan sampel untuk siswa adalah 20\%, yaitu sebanyak 21 orang siswa yang diambil secara acak pada tiap kelasnya. Data dalam penelitian ini dikumpulkan dengan menggunakan teknik observasi, dan dokumentasi. Selanjutnya data yang terkumpul dianalisa dengan menggunakan rumus uji t.

Berdasarkan analisa data melalui observasi pada penelitian ini dapat disimpulkan bahwa motivasi guru di Madrasah Ibtidaiyah Pondok Pesantren Al-Rasyid Simpang Jaya Kecamatan Batang Tuaka, mencapai angka 55,95\% dan dikategorikan cukup baik. Karena angka 55,95\% terletak pada interval $41 \%-60 \%$. aktivitas belajar siswa kelas tinggi di Madrasah Ibtidaiyah Pondok Pesantren Al-Rasyid Simpang Jaya Kecamatan Batang Tuaka, mencapai angka $49,64 \%$ dan dikategorikan cukup baik. Karena angka $49,64 \%$ terletak pada interval $41 \%$ $60 \%$. Tidak terdapat pengaruh yang positif dan signifikan antara motivasi guru terhadap aktivitas belajar siswa kelas tinggi di Madrasah Ibtidaiyah Pondok Pesantren Al-Rasyid Simpang Jaya Kecamatan Batang Tuaka, yang ditunjukkan dengan angka -0,12 dan diinterpretasikan sangat rendah. Karena berdasarkan tabel t, nilai untuk 23 adalah 1,714. Sehingga $t_{\text {hitung }} \leq t_{\text {tabel }}$, artinya $t_{\text {hitung }} \leq t_{\text {tabel }}=-0,12 \leq 1,714$, maka $H_{o}$ diterima, angka 0,12 terletak pada daerah penolakan, maka $\mathrm{H}_{\mathrm{a}}$ ditolak dan $\mathrm{H}_{\mathrm{o}}$ diterima.
\end{abstract}

Kata Kunci: Motivasi Guru, Aktivitas Belajar Siswa.

\section{A. PENDAHULUAN}

\section{Latar belakang}

Di era globalisasi ini, masih ada program pembelajaran seakan-akan belum dapat memberikan hasil yang memuaskan. Jika proses pembelajaran berlangsung, suasana kelas nampak tegang dan membosankan. Guru sibuk menyampaikan materi tanpa mau tahu tentang siswanya paham atau tidak. "Paham tidak paham asal materi habis dan urusan menjadi beres". "Kebanyak an guru dalam mendidik selalu monoton atau tidak melakukan variasi-variasi”. ${ }^{1}$

Oleh karena itu, untuk membantu siswa menumbuh kembangkan aspek-

${ }^{1}$ Dirto Hadi Susanto, Kapita Selekta Pendidikan, (Yogyakarta: FKIP, 2007), h. 2 
aspek dirinya, perlu dikembangkan strategi pembelajaran yang tidak hanya menekankan aspek ingatan, hafalan, berbasis materi, namun sampai pada aspek penalaran dan kemampuan menggunakan keterampilan secara baik serta sifat berpikir yang aktif-positif. Salah satu caranya dengan menumbuhkan motivasi belajar dalam diri siswa melalui berbagai strategi.

Kegiatan belajar, motivasi dapat dikatakan sebagai keseluruhan daya penggerak di dalam diri siswa yang menimbulkan, menjamin kelangsungan dan memberikan arah kegiatan belajar, sehingga diharapkan tujuan dapat tercapai. Motivasi sangat diperlukan di dalam kegiatan belajar, sebab seseorang yang tidak mempunyai motivasi dalam belajar, tidak akan mungkin melakukan aktivitas belajar. Dari uraian di atas, jelaslah bahwa motivasi dalam belajar perlu ditanamkan dan ditumbuh kembangkan.

Sedangkan pendidikan mempunyai misi yang berkaitan dengan pembinaan dan peningkatan kualitas sumber daya manusia. Kualitas pendidikan seyogya nya dinilai dari keberhasilannya, sehingga manusia itu dapat memberikan konstribusi yang berarti bagi kesejahtera an dirinya dan kesejahteraan manusia pada umumnya. Orientasi pendidikan dalam memberikan pembinaan meng hadapi masa depan akan selalu ditandai oleh berbagai perubahan, anatara lain mutu dan kualitas guru dalam pembelajaran. Dalam hal ini sebagaimana yang diutarakan oleh Mulyasa;

"Pendidikan dan pembinaan guru serta tenaga kependidikan lainnya pada semua jenjang dan jenis pendidikan perlu ditingkatkan pengembangan karier dan kesejahteraan. Keberhasialn suatu proses pendidikan sangat bergantung pada kinerja guru. ${ }^{2}$

Guru sebagai penanggung jawab kelancaran proses pembelajaran dan jika proses pembelajaran itu ingin berhasil dengan baik tentu guru setiap hari atau pada waktu jam mengajar telah berada di tempat/di dalam kelas, kemudian melaksanakan pembelajaran dengan membimbing, membantu, mendorong dan memberikan arahan sehingga proses tersebut berjalan dengan efektif, agar terwujud aktivitas belajar yang lebih baik.

Akan tetapi melalui pengamatan pendahuluan yang dilakukan penulis di Madrasah Ibtidaiyah Pondok Pesantren Al-Rasyid Simpang Jaya Kecamatan Batang Tuaka, ditemukan sebagai berikut:

Guru telah memberikan motivasi namun aktivitas belajar yang dilakukan siswa masih monoton. Guru telah memotivasi siswa dengan memberikan pujian, namun setelah dipuji siswa justru malu melakukan aktivitas belajar. Penulis juga melihat siswa telah melakukan aktivitas belajar berupa membaca, namun tidak dilakukan secara tepat. Ada juga sebagian siswa yang senang menulis, namun tidak dapat menjawab pertanyaan secara lisan.

Istilah motivasi berpangkal dari kata motif yang dapat diartikan sebagai daya penggerak yang ada di dalam diri seseorang untuk melakukan aktivitas-

${ }^{2}$ Rohman, Pendidikan Guru dalam Arus Perubahan; Konvensi pendidikan II, (Medan: Purnama, 1999), h. 23. 
aktivitas tertentu demi tercapainya suatu tujuan. Bahkan motif dapat diartikan sebagai suatu kondisi kesiapsiagaan. Menurut Mc. Donald dalam Sobry Sutikno, motivasi adalah "perubahan energi dalam diri seseorang yang ditandai dengan munculnya feeling dan didahului dengan tanggapan terhadap adanya tujuan". 3

Senada dengan ungkapan di atas, Wina Sanjaya menjelaskan bahwa motivasi adalah

"Dorongan yang dapat menimbul kan perilaku tertentu yang terarah kepada pencapaian suatu tujuan tertentu. Perilaku atau tindakan yang ditujukan seseorang dalam upaya mencapai tujuan tertentu sangat tergantung dari motive yang dimilikinya." 4

Dalam buku yang sama, Hilgard mengatakan bahwa motivasi adalah "suatu keadaan yang terdapat dalam diri seseorang yang menyebabkan seseorang melakukan kegiatan tertentu untuk mencapai tujuan tertentu". 5

Dari pengertian di atas dapat diketahui bahwa dalam motivasi terkandung tiga elemen atau ciri pokok dalam motivasi, yakni motivasi itu mengawali terjadinya perubahan energi, ditandai dengan adanya feeling, dan dirangsang karena adanya tujuan.

Dalam kegiatan belajar, motivasi dapat dikatakan sebagai keseluruhan daya penggerak di dalam diri siswa yang

${ }^{3}$ M. Sobry Sutikno, Belajar dan Pembelajaran; Upaya Kreatif dalam Mewujudkan Pembelajaran yang Berhasil, (Bandung: Prospect, 2009), h. 71.

${ }^{4}$ Wina Sanjaya, Kurikulum dan Pembelajaran, Teori dan Pengembangan KTSP, (Jakarta: Prenada Media Group, 2008), h 250.

${ }^{5}$ Ibid., menimbulkan, menjamin kelangsungan dan memberikan arah kegiatan belajar, sehingga diharapkan tujuan dapat tercapai. Motivasi sangat diperlukan di dalam kegiatan belajar, tidak akan mungkin melakukan aktivitas belajar. Ada tiga komponen utama dalam motivasi, yaitu: "kebutuhan, dorongan, dan tujuan. Kebutuhan terjadi bila individu merasa ada ketidakseimbangan antara apa yang ia miliki dan yang ia harapkan". 6

Sebagai ilustrasi, siswa merasa bahwa hasil belajarnya rendah, padahal ia memiliki buku pelajaran lengkap. Ia merasa memiliki cukup waktu, tetapi ia kurang baik mengatur waktu belajar. Waktu belajar yang digunakannya tidak memadai untuk memperoleh hasil belajar yang baik. Ia membutuhkan hasil belajar yang baik. Oleh karena itu siswa mengubah cara-cara belajarnya. Dorongan merupakan kekuatan mental untuk melakukan kegiatan dalam rangka memenuhi harapan. Dorongan merupa kan kekuatan mental yang berorientasi pada pemenuhan harapan atau pencapaian tujuan. Dorongan yang berorientasi pada tujuan tersebut merupakan inti motivasi. Motivasi ada dua, yaitu "motivasi intrinsik, dan motivasi ekstrinsik, yang saling berkaitan satu dengan lainnya. ${ }^{7}$

Motivasi intrinsik, jenis motivasi ini timbul dari dalam diri individu sendiri tanpa ada paksaan dorongan orang lain. Motivasi ini sering disebut "motivasi

${ }^{6}$ Nasution, Berbagai Pendekatan Dalam Proses Belajar dan Mengajar, (Jakarta: PT. Bumi Aksara, 2000), h.16.

${ }^{7}$ Pupuh Fathurrahman, Strategi Belajar Mengajar, (Bandung: Refika Aditama, 2007),h. 99. 
murni”, atau motivasi yang sebenarnya, yang timbul dari dalam diri siswa, misalnya keinginan untuk mendapatkan keterampilan tertentu, mengembang kan sikap untuk berhasil, dan sebagainya.

Motivasi ekstrinsik, jenis motivasi ini timbul sebagai akibat pengaruh dari luar individu, apakah karena adanya ajakan, suruhan, atau paksaan dari orang lain sehingga dengan keadaan demikian siswa mau melakukan sesuatu. Motivasi ekstrinsik diperlukan di sekolah sebab pembelajaran di sekolah tidak semuanya menarik minat, atau sesuai dengan kebutuhan siswa. Kalau keadaan seperti ini, maka siswa bersangkutan perlu dimotivasi agar belajar, dan guru harus berusaha membangkitkan motivasi belajar siswa sesuai dengan keadaan siswa itu sendiri.

\section{Fungsi Motivasi dalam Belajar}

Pembelajaran akan berhasil manakala siswa memiliki motivasi dalam belajar. Oleh sebab itu, untuk menumbuhkan motivasi belajar siswa, merupakan salah satu tugas dan tanggung jawab guru. Guru yang baik dalam mengajar selamanya akan berusaha mendorong siswa untuk beraktivitas mencapai tujuan pembelajar an. Ada dua fungsi motivasi dalam proses pembelajaran, yakni "mendorong siswa untuk beraktivitas dan pengarah". 8

Sedangkan menurut Sardiman, A.M., motivasi dapat berfungsi sebagai pendorong usaha dan pencapaian prestasi. Seseorang melakukan suatu usaha karena adanya motivasi. Adanya motivasi yang baik dalam belajar akan

${ }^{8}$ Sumadi Suryabrata, Psikologi Pendidikan, (Yogyakarta: Rake Press, 2003), h. 73. menunjukkan hasil yang baik. Dengan kata lain, dengan adanya usaha yang tekun dan terutama didasari adanya motivasi, maka seseorang yang belajar itu akan dapat melahirkan prestasi yang baik. Intensitas motivasi seorang siswa akan sangat menentukan tingkat pencapaian prestasi belajarnya. $^{9}$

Nampak jelas di sini bahwa motivasi berfungsi sebagai pendorong, pengarah, dan sekaligus penggerak perilaku seseorang untuk mencapai suatu tujuan.

Berbicara tentang macam atau jenis motivasi ini dapat dilihat dari berbagai sudut pandang. Dengan demikian, motivasi atau motif-motif yang aktif itu sangat bervariasi. Dilihat dari dasar pembentukkannya, motivasi dibagi ke dalam "motivasi bawaan dan motivasi yang dipelajari". ${ }^{10}$ Yang dimaksud dengan motivasi bawaan adalah motivasi yang dibawa sejak lahir, jadi motivasi itu ada tanpa dipelajari. Sebagai contoh dorongan untuk makan, dorongan untuk minum, dorongan untuk bekerja, untuk beristirahat, dan dorongan seksual. Sedangkan motivasi yang dipelajari adalah motivasi yang timbul karena dipelajari. Sebagai contoh dorongan untuk belajar suatu cabang ilmu pengetahuan, dorongan untuk mengajar sesuatu di dalam masyarakat.

\section{Langkah-Langkah Melakukan \\ Motivasi dalam Belajar \\ Di dalam kegiatan belajar mengajar} peranan motivasi baik intrinsik maupun ekstrinsik sangat diperlukan. Dengan motivasi, pelajar dapat mengembangkan

\footnotetext{
${ }^{9}$ Sardiman, A.M, Op.Cit., hlm. 86.

${ }^{10}$ Winarno Surakhmad, Pengantar Interaksi Belajar Mengajar, (Bandung: Transifo, 2002), h.
} 82. 
aktivitas dan inisiatif, dapat mengarahkan dan memelihara ketekunan dalam melakukan kegiatan belajar. Dalam kaitan itu perlu diketahui bahwa cara dan jenis menumbuhkan motivasi adalah bermacam-macam. Tetapi untuk motivasi ekstrinsik kadang-kadang tepat, dan kadang-kadang juga bisa kurang sesuai. Dalam hal inilah kemampuan guru dalam menumbuhkan dan memberi motivasi bagi kegiatan belajar siswa ditantang. Sebab mungkin maksudnya memberikan motivasi tetapi justru tidak menguntungkan perkembangan belajar siswa.

Ada beberapa bentuk dan cara untuk menumbuhkan motivasi dalam kegiatan belajar di sekolah, yaitu: (1) Tujuan, (2) Ulangan, (3) Nilai, (4) Hadiah, (5) Memberitahukan hasil belajar, (6) Pujian, dan (7) Hukuman. ${ }^{11}$

Secara rinci kutipan di atas diuraikan sebagi berikut:

a. Tujuan. Tujuan adalah suatu cita-cita yang ingin dicapai dari pelaksanaan suatu kegiatan. Tidak ada suatu kegiatan yang diprogram kan tanpa tujuan karena hal itu adalah suatu hal yang tidak memiliki kepastian dalam menentukan ke arah mana kegiatan itu akan dibawa. ${ }^{12}$ Sebagai unsur penting untuk suatu kegiatan, maka dalam kegiatan apapun tujuan tidak bisa diabaikan. Demikian juga halnya dalam kegiatan belajar mengajar. Dalam kegiatan belajar mengajar, tujuan adalah suatu cita-cita yang dicapai dalam kegiatannya. Kegiatan belajar mengajar tidak bisa dibawa

${ }^{11}$ Sardiman, A.M, op, cit., h. 92-93.

${ }^{12}$ Syaiful Bahri Djamarah, Strategi Belajar Mengajar, (Jakarta: Rineka Cipta, 2006), h. 42. sesuka hati, kecuali untuk mencapai tujuan yang telah ditetapkan. Rumusan tujuan yang diakui dan diterima baik oleh siswa, akan merupakan alat motivasi yang sangat penting. Sebab dengan memahami tujuan yang harus dicapai, karena dirasa sangat berguna dan menguntungkan, maka akan timbul gairah untuk terus belajar. ${ }^{13}$ Belajar merupakan kegiatan pokok dalam pendidikan. Berbagai upaya yang dilakukan oleh guru dalam proses pembelajaran, intinya adalah upaya untuk membuat siswa belajar. Alangkah sia-sia upaya yang dilakukan oleh guru jika dengannya siswa tidak mau belajar. Oleh karena itu pada permulaan pembelajaran seharus nya terlebih dahulu guru menjelaskan mengenai tujuan pembelajaran khusus yang akan dicapai oleh siswa. ${ }^{14}$ Makin jelas tujuan maka makin besar pula motivasi belajar siswa.

b. Memberi Ulangan. Ulangan adalah "seperangkat soal yang harus dijawab para siswa dan tugas-tugas terstruktur yang berkaitan dengan konsep yang sedang dibahas". ${ }^{15}$ Para siswa akan menjadi giat belajar kalau mengetahui akan ada ulangan. Oleh karena itu, memberi ulangan ini juga merupakan sarana motivasi. Tetapi yang harus diingat oleh guru adalah jangan terlalu sering (misalnya setiap hari) karena bisa membosankan dan

${ }^{13}$ M.Sobry Sutikno, op.cit., h. 6.

${ }^{14}$ Ibid., h. 19.

${ }^{15}$ Kunandar, Guru Profesional Implementasi KTSP dan Sukses dalam Sertifikasi Guru, (Jakarta: Raja Grafindo Persada, 2008), h. 384. 
bersifat rutinitas. Dalam hal ini guru harus juga terbuka, maksudnya kalau akan ulangan harus diberitahukan kepada siswanya.

c. Memberi Nilai. Dalam kamus Bahasa Indonesia nilai diartikan sebagai "harga, kadar mutu". ${ }^{16}$ Dalam proses pembelajaran nilai diberikan dalam bentuk angka. Angka dalam hal ini sebagai simbol dari nilai kegiatan belajarnya. Banyak siswa belajar, yang utama justru untuk mencapai angka/nilai yang baik. Sehingga siswa biasanya yang dikejar adalah nilai ulangan atau nilai-nilai pada raport angkanya baik-baik. Angka-angka yang baik itu bagi para siswa merupakan motivasi yang sangat kuat. Tetapi ada juga, bahkan banyak siswa bekerja atau belajar hanya ingin mengejar pokoknya naik kelas saja. Ini menunjukkan motivasi yang dimilikinya kurang berbobot bila dibandingkan dengan siswa-siswa yang menginginkan angka baik. Namun demikian, semua itu harus diingat oleh guru bahwa pencapaian angka-angka seperti itu belum merupakan hasil belajar yang sejati, hasil belajar yang bermakna. Oleh karena itu, langkah selanjutnya yang ditempuh oleh guru adalah bagaimana cara memberikan angka-angka dapat dikaitkan dengan values yang terkandung di dalam setiap pengetahuan yang diajarkan kepada para siswa sehingga tidak sekadar kognitif saja tetapi juga keterampilan dan afeksinya.

${ }^{16}$ Tim Reality, op.cit., h. 468. d. Hadiah. Hadiah adalah "pemberian dari seseorang karena prestasi". ${ }^{17}$ Hadiah dapat juga dikatakan sebagai motivasi, tetapi tidaklah selalu demikian. Karena hadiah untuk suatu pekerjaan, mungkin tidak akan menarik bagi seseorang yang tidak senang dan tidak berbakat untuk sesuatu pekerjaan tersebut. Sebagai contoh hadiah yang diberikan untuk gambar yang terbaik mungkin tidak akan menarik bagi seseorang siswa yang tidak memiliki bakat menggambar.

e. Memberitahukan Hasil Belajar. Dengan mengetahui hasil pekerjaan, apalagi kalau terjadi kemajuan, akan mendorong siswa untuk lebih giat belajar. Semakin mengetahui bahwa grafik hasil belajar meningkat, maka ada motivasi pada diri siswa untuk terus belajar, dengan suatu harapan hasilnya terus meningkat.

f. Memberi Pujian. Apabila ada siswa yang sukses yang berhasil menyelesaikan tugas dengan baik, perlu diberikan pujian. Pujian ini adalah "bentuk reinforcement yang positif dan sekaligus merupakan motivasi yang baik". ${ }^{18}$ Oleh karena itu, supaya pujian ini merupakan motivasi, pemberiannya harus tepat. Dengan pujian yang tepat akan memupuk suasana yang menyenangkan dan memper tinggi gairah belajar serta sekaligus akan membangkitkan harga diri. Pujian adalah "alat motivasi yang positif. Setiap orang senang dipuji."19 Tak

${ }^{17}$ Ibid., h. 271.

${ }^{18}$ Ibid., h. 135.

${ }^{19}$ Syaiful Bahri Djamarah, op.cit., h. 152. 
peduli tua atau muda, bahkan anakanak pun senang dipuji atas sesuatu pekerjaan yang telah selesai dikerjakannya dengan baik. Dalam kegiatan belajar mengajar, pujian dapat dimanfaatkan sebagai alat motivasi. Karena anak didik juga manusia, maka dia juga senang dipuji. Guru dapat memakai pujian untuk menyenangkan perasaan anak didik. Anak didik senang mendapat perhatian dari guru. Dengan pemberian perhatian, anak didik merasa diawasi dan dia tidak akan dapat berbuat menurut sekehendak hatinya. Pujian dapat berfungsi untuk mengarahkan kegiatan anak didik pada hal-hal yang menunjang tercapainya tujuan pengajaran. Namun begitu, pujian harus betulbetul sesuai dengan hasil kerja anak didik. Jangan memuji secara berlebihan. Pujian secara berlebihan akan terkesan sebaliknya, yaitu pujian yang dibuat-buat. Pujian yang baik adalah pujian keluar dari hati seorang guru secara wajar dengan maksud untuk memberikan penghargaan kepada anak didik atas jerih payahnya dalam belajar. Pujian tidak hanya dapat diberikan kepada seorang anak didik, tetapi dapat juga diberikan kepada semua anak didik. Tetapi pujian tidak diberikan kepada anak didik sebelum mereka menyelesaikan pekerjaanya.

g. Memberi Hukuman. Hukuman sebagai reinforcement yang negatif tetapi kalau diberikan secara tepat dan bijak bisa menjadi alat motivasi. Oleh karena itu guru harus memahami prinsip-prinsip pemberi an hukuman.
Di samping bentuk-bentuk motivasi sebagaimana diuraikan di atas, sudah barang tentu masih banyak bentuk dan cara yang bisa dimanfaatkan. Hanya yang penting bagi guru adanya bermacam-macam motivasi itu dapat dikembangkan dan diarahkan untuk dapat melahirkan hasil belajar yang bermakna.

\section{Pengertian Aktivitas Siswa}

Aktivitas yang harus dilakukan guru dan siswa dalam proses pembelajaran beragam. Dalam kamus bahasa Indonesia, aktivitas diartikan sebagai "kegiatan, hal-hal yang dilakukan, pekerjaan". ${ }^{20}$

Dalam kehidupan sehari-hari, aktivitas lebih dikenal sebagai "suatu rutinitas yang dilaksanakan secara terusmenerus". ${ }^{21}$

Siswa adalah murid yang belajar. Dengan demikian aktivitas siswa dapat dimaknai sebagai rangkaian kegiatan yang dilakukan oleh siswa dalam proses pembelajaran. Aktivitas siswa tersebut dapat berlangsung di dalam ataupun di luar kelas.

Hubungannya dengan penelitian ini, aktivitas belajar merupakan kegiatan yang dilakukan siswa dalam proses pembelajaran pada mata pelajaran Pendidikan Agama Islam. Pada proses pembelajaran, guru perlu menerapkan pembelajaran yang mengaktifkan siswa. Sehingga dengan demikian, aktivitas siswa dalam belajar perlu dibangkitkan dan dikembangkan. Adapun untuk

${ }^{20}$ Tim Reality, Kamus Bahasa Indonesia, (Surabaya: Reality Publisher, 2008), h. 31.

${ }^{21}$ Gafar Ginandjar, Kiat Mengatasi Kejenuhan dalam Aktivitas, (Bandung: Perpect, 2007), h. 62. 
mewujudkan hal tersebut, ada banyak strategi dan metode yang dapat guru lakukan. Pada siswa yang pasif, biasanya siswa hanya datang, duduk dengan rapi, mendengarkan tanpa bergerak sedikitpun ceramah yang diberikan oleh guru kemudian pulang. Hal tersebut sangat disayangkan pada saat era modern saat ini. Pada dasarnya, ada banyak sekali aktivitas belajar siswa yang perlu dibangkitkan dan dikem- bangkan oleh guru, di antaranya adalah menurut Wasty Soemanto," belajar adalah proses dimana tingkah laku ditimbulkan atau diubah melalui latihan atau pengalaman". ${ }^{22}$ Dalam hal ini aktivitas ditekankan pada kegiatan latihan dan pengalaman yang terjadi dalam proses belajar.

Menurut Howard L Kingsley dalam buku yang sama dijelaskan bahwa "belajar adalah proses dimana tingkah laku (dalam artian luas) ditimbulkan atau diubah melalui praktek atau latihan". 23 Dengan demikian jelaslah bahwa belajar merupakan aktivitas. Karena kegiatan belajar mengandung aktivitas latihan yang pada akhirnya menghasilkan perubahan tingkah laku. Menurut J.B. Watson dalam Djiwandono-siti Nuryani "belajar adalah suatu proses dari respon melalui pergantian dari stimulus kepada yang lain". ${ }^{24}$

Kesimpulannya adalah bahwa belajar merupakan proses dasar dari perkembangan hidup manusia. Dengan belajar, manusia melakukan perubahan-

${ }^{22}$ Wasty Soemanto, Psikologi Pendidikan, (Jakarta: Rineka Cipta, 1998), h. 104.

${ }^{23}$ Ibid., h.105.

${ }^{24}$ Djiwandono dan Siti Nuryani, Psikologi Pendidikan, (Jakarta: Grasindo Persada, 2002), h, 129. perubahan kualitatif individu sehingga tingkah lakunya berkembang. Semua aktivitas dan prestasi hidup manusia tidak lain adalah hasil dari belajar. Belajar bukan sekedar pengalaman, tapi suatu proses, karena belajar berlangsung secara aktif dan integratif dengan menggunakan berbagai bentuk perbuatan untuk mencapai suatu tujuan.

Aktivitas belajar menurut $\mathrm{H}$. Abu Ahmadi dan Widodo Supriyono, antara lain adalah:

a. Mendengarkan. Dalam kehidupan sehari-hari kita bergaul dengan orang lain. Dalam pergaulan itu terjadi komunikasi verbal berupa percakap an. Percakapan memberikan situasi tersendiri bagi orang-orang yang terlibat ataupun yang tidak terlibat tetapi secara tidak langsung mendengar informasi. Situasi ini memberi kesempatan kepada seseorang untuk belajar.

b. Memandang. Dalam kehidupan sehari-hari banyak hal yang dapat kita pandang, akan tetapi tidak semua pandangan atau penglihatan kita adalah belajar.

c. Meraba, mencium, dan mencicipi. Merupakan aktivitas sensoris dan memberikan kesempatan kepada seseorang untuk belajar.

d. Menulis atau mencatat. Menulis atau mencatat isi buku, ceramah, hasil diskusi dan sebagainya merupakan aktivitas belajar, namun menjiplak atau mengopi tidak dapat dikatakan sebagai aktivitas belajar.

e. Membaca. Membaca dapat dikatakan belajar jika mempunyai tujuan dan dilaksanakan dengan serius. Jika membaca sambil baring dengan 
maksud santai bukanlah aktivitas belajar.

f. Membuat ikhtisar, ringkasan, atau menggarisbawahi.

g. Mengamati tabel, diagram, atau bagan.

h. Menyusun paper atau kertas kerja.

i. Mengingat.

j. Berpikir dan latihan, atau praktek. ${ }^{25}$

Kesepuluh aktivitas belajar di atas selalu dilaksanakan secara bersamaan antara dua atau tiga aktivitas sekaligus, bahkan ada juga sampai lima aktivitas. Misalnya guru mendiktekan sesuatu, maka aktivitas belajar yang dilakukan siswa adalah mendengar, menulis, dan mengingat, atau bahkan membaca, yang kesemuanya dilaksanakan secara bersamaan.

Sumadi Suryabrata memiliki sudut pandang yang berbeda dalam menyebutkan aktivitas belajar siswa. Menurutnya aktivitas belajar siswa tersebut meliputi hal-hal sebagai berikut:

a. Hadir saat proses pembelajaran.

b. Mengerjakan tugas.

c. Mencatat penjelasan guru.

d. Melaksanakan evaluasi pembelajaran.

e. Mengulangi pelajaran di rumah. ${ }^{26}$

Kehadiran dalam proses pembelajar an merupakan aktivitas utama dalam belajar. Karena tanpa menghadiri proses pembelajaran, aktivitas belajar yang lainnya tidak dapat dilakukan.

Aktivitas belajar selanjutnya adalah mengerjakan tugas yang diberikan guru, memperhatikan penjelasan guru, dan

${ }^{25}$ H. Abu Ahmadi dan Widodo Supriyono, Psikologi Belajar, (Jakarta: Rineka Cipta, 2004), h. 132-137.

${ }^{26}$ Sumadi Suryabrata, Psikologi Pendidikan, (Jakarta: Rajawali Press, 2004), h. 84. mencatat hal-hal penting sebagai ikhtisar. Materi yang telah dicatat diulangi dirumah sebagai persiapan untuk mengikuti evaluasi.

Menurut Sardiman A.M, yang mengutip pendapat Paul B. Diedrich dalam buku Interaksi dan Motivasi Belajar Mengajar, aktivitas belajar siswa digolongkan sebagai berikut:

a. Visual activities, yang termasuk di dalamnya misalnya, membaca, memerhatikan gambar demonstrasi, percobaan, pekerjaan orang lain.

b. Oral activities, seperti: menyatakan, merumuskan, bertanya, memberi saran, mengeluarkan pendapat, mengadakan wawancara, diskusi, interupsi.

c. Listening activities, sebagai contoh mendengarkan: uraian, percakapan, diskusi, musik, pidato.

d. Writing activities, seperti misalnya menulis cerita, karangan, laporan, angket, menyalin.

e. Drawing activities, misalnya: menggambar, membuat grafik, peta, diagram.

f. Motor activities, yang termasuk di dalamnya antara lain: melakukan percobaan, membuat konstruksi, model mereparasi, bermain, berkebun, beternak.

g. Mental activities, sebagai contoh misalnya: menanggapi, mengingat, memecahkan soal, menganalisis, melihat hubungan, mengambil keputusan.

h. Emotional activities, seperti misalnya, menaruh minat, merasa bosan, 
gembira, bersemangat, bergairah, berani, tenang, gugup. ${ }^{27}$

Jadi dengan klasifikasi aktivitas seperti diuraikan di atas, menunjukkan bahwa aktivitas di sekolah cukup kompleks dan bervariasi. Kalau berbagai macam kegiatan tersebut dapat diciptakan di sekolah, tentu sekolahsekolah akan lebih dinamis, tidak membosankan dan benar-benar menjadi pusat aktivitas belajar yang maksimal dan bahkan akan memperlancar peranannya sebagai pusat dan transformasi kebudayaan. Tetapi sebalik nya ini semua merupakan tantangan yang menuntut jawaban dari para guru. Kreativitas guru mutlak diperlukan agar dapat merencanakan kegiatan siswa yang sangat bervariasi itu.

Dari uraian di atas dapat disimpulkan bahwa aktivitas belajar siswa, khususnya pada mata pelajaran Pendidikan Agama Islam antara lain adalah sebagai berikut:

a. Visual activities: membaca materi pembelajaran, memperhatikan pekerja an guru.

b. Oral activities: menyatakan pendapat dalam pembelajaran, merumuskan kesimpulan dalam pembelajaran, bertanya dalam pembelajaran, mengeluarkan pendapat dalam pembelajaran. berdiskusi dalam pembelajaran.

c. Listening activities: mendengarkan penjelasan guru dalam pembelajaran.

d. Writing activities: menyalin hal-hal penting dalam pembelajaran.

e. Mental activities: menanggapi pendapat teman dalam pembelajaran,

${ }^{27}$ Sardiman A.M, op.cit., h. 101. mengerjakan soal latihan dalam pembelajaran.

\section{B. METODOLOGI}

Subjek dalam penelitian ini adalah guru dan siswa kelas tinggi di Madrasah Ibtidaiyah Pondok Pesantren Al-Rasyid Simpang Jaya Kecamatan Batang Tuaka. Sedangkan objek dalam penelitian ini adalah pengaruh motivasi guru terhadap aktivitas belajar siswa kelas tinggi di Madrasah Ibtidaiyah Pondok Pesantren Al-Rasyid Simpang Jaya Kecamatan Batang Tuaka. Populasi dalam penelitian ini adalah seluruh guru dan siswa kelas tinggi di Madrasah Ibtidaiyah Pondok Pesantren Al-Rasyid Simpang Jaya Kecamatan Batang Tuaka, yang berjumlah 4 orang guru dan 132 orang siswa. Sedangkan sampel diambil sebanyak 20\%. adalah 21 orang siswa yang diambil secara acak atau random sampling. Teknik Pengumpulan Data: Observasi, Dokumentasi. Teknik Analisa Data menentukan berpengaruh atau tidaknya pelaksanaan evaluasi non test terhadap prestasi belajar siswa di cari dengan rumus uji $\mathrm{t}$ :

$\mathrm{t}=\left(\mathrm{X}-\mathrm{Y} \overline{)} / \sqrt{ }\left(\mathrm{S} \_(\mathrm{x}-\mathrm{y})^{\wedge} 2\left(1 / \mathrm{n} \_\mathrm{x}+1 / \mathrm{n} \_\mathrm{y}\right)\right)\right.$

Keterangan:

$\mathrm{t}=$ nilai deviasi pada distribusi $\mathrm{t}$

$\mathrm{X}$ = nilai rata-rata variabel $\mathrm{X}$

$\mathrm{Y}=$ nilai rata-rata variabel $\mathrm{Y}$

$\mathrm{S}^{2} \mathrm{x}-\mathrm{y}=$ standar deviasi

$\mathrm{nx} \quad=$ jumlah sampel $\mathrm{X}$

ny = jumlah sampel $\mathrm{Y}$

Terlebih dahulu mencari nilai rata-rata variabel $X$, yaitu:

Nilai $X^{-}=\left(\sum X\right) / n \_X$

Selanjutnya mencari nilai rata-rata variabel $\mathrm{Y}$, yaitu:

Nilai $\mathrm{Y}^{-}=\left(\sum \mathrm{Y}\right) / \mathrm{n} \_\mathrm{y}$ 
Selanjutnya mencari varians ( $\left.\mathrm{S}^{2} \mathrm{xy}\right)$ dengan rumus sebagai berikut:

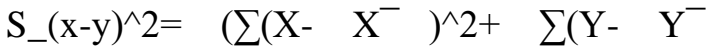
)$\left.^{\wedge} 2\right) /\left(\mathrm{n} \_\mathrm{x}+\mathrm{n} \_\mathrm{y}-2\right)$

Kriterianya adalah Jika - ttabel $\leq$ thitung $\leq$ ttabel, maka Ho diterima, dan Ha di tolak.

\section{B. PEMBAHASAN}

Dari tabel di atas diketahui bahwa dari keseluruhan hasil observasi didapat hasil 344 kali aspek ya $(49,64 \%)$, dan 349 kali aspek tidak $(50,36 \%)$, dengan jumlah total 693 (100\%). Selanjutnya hasil observasi ya diberi skor 1 dan hasil observasi tidak diberi skor $0 .^{28}$ Maka didapat hasil setelah penskoran sebagai berikut:

$$
\begin{array}{ll}
\text { Ya } & =344 \times 1=344 \\
\text { Tidak } & =349 \times 0=0 \\
\text { Jumlah Total } & =344
\end{array}
$$

Maka F = 344, dan N = Jumlah

Populasi x Jumlah Aspek yang Diobservasi x Jumlah Observasi x Skor Tertinggi $=21 \times 11 \times 3 \times 1=693$

Untuk mengetahui aktivitas belajar siswa kelas tinggi di Madrasah Ibtidaiyah Pondok Pesantren Al-Rasyid Simpang Jaya Kecamatan Batang Tuaka, digunakan rumus: $\mathrm{P}=\frac{\mathrm{F}}{\mathrm{N}} \times 100 \%$ $\mathrm{P}=\frac{344}{693} \times 100 \%=49,64 \%$

Dengan demikian dapat diketahui bahwa aktivitas belajar siswa kelas tinggi di Madrasah Ibtidaiyah Pondok Pesantren Al-Rasyid Simpang Jaya Kecamatan Batang Tuaka, mencapai angka 49,64\% dan dikategorikan cukup baik. Karena angka 49,64\% terletak pada interval $41 \%-60 \%$.

\footnotetext{
${ }^{28}$ Belajar Ibid., h. 91.
}

Untuk melakukan pembahasan terhadap data hasil penelitian ditempuh langkah-langkah sebagai berikut:

\section{Langkah Pertama:}

Membuat Ha dan Ho dalam bentuk kalimat di bawah ini:

$\mathrm{Ha}$ :Terdapat pengaruh yang positif dan signifikan antara motivasi guru terhadap aktivitas belajar siswa kelas tinggi di Madrasah Ibtidaiyah Pondok Pesantren Al-Rasyid Simpang Jaya Kecamatan Batang Tuaka.

Ho :Tidak terdapat pengaruh yang positif dan signifikan antara motivasi guru terhadap aktivitas belajar siswa kelas tinggi di Madrasah Ibtidaiyah Pondok Pesantren Al-Rasyid Simpang Jaya Kecamatan Batang Tuaka.

\section{Langkah Kedua:}

Membuat Ha dan Ho dalam bentuk statistik, yaitu:

$$
\begin{array}{ll}
\text { Ha : } & r \neq 0 \\
\text { Ho : } & r=0
\end{array}
$$

\section{Langkah ketiga:}

Membuat tabel penolong untuk menghitung angka statistik dengan cara sebagai berikut:

$$
\begin{array}{ll}
\mathrm{n}=4 & \sum \mathrm{X}=47 \\
\mathrm{n}=21 & \sum \mathrm{Y}=344
\end{array}
$$

\section{Langkah Keempat:}

Mencari rata-rata variabel $\mathrm{X}$ dan rata-rata variabel $\mathrm{Y}$ :

Rata-Rata Variabel X

$$
\text { Nilai } \bar{X}=\frac{\sum X}{n_{x}} \text { Nilai } \bar{X}=\frac{47}{4}=11,75
$$

Dengan demikian diketahui bahwa rata-rata variabel $\mathrm{X}=11,75$

Rata-Rata Variabel Y

$$
\text { Nilai } \bar{Y}=\frac{\sum Y}{n_{y}} \text { Nilai } \bar{Y}=\frac{344}{21}=16,38
$$


Dengan demikian diketahui bahwa rata-rata variabel $\mathrm{Y}=16,38$

\section{Langkah Kelima}

Mencari varians $\left(\mathrm{S}^{2} \mathrm{x}-\mathrm{y}\right)$ dengan rumus:

$$
\begin{aligned}
S_{x-y}^{2} & =\frac{\sum(X-\bar{X})^{2}+\sum(Y-\bar{Y})^{2}}{\left(n_{x}+n_{y}\right)-2} \\
S_{x-y}^{2}= & \frac{(47-11,75)^{2}+(344-16,38)^{2}}{(4+21)-2} \\
S_{x-y}^{2} & =\frac{(35,25)^{2}+(327,62)^{2}}{(25)-2} \\
S_{x-y}^{2} & =\frac{1242,56+107334,86}{23} \\
S_{x-y}^{2} & =\frac{108577,42}{23}=4720,76
\end{aligned}
$$

\section{Langkah Keenam}

Menentukan nilai deviasi pada distribusi dengan menggunakan rumus thitung:

$$
\begin{gathered}
t=\frac{\bar{X}-\bar{Y}}{\sqrt{S_{x-y}^{2}\left(\frac{1}{n_{x}}+\frac{1}{n_{y}}\right)}} \\
t=\frac{11,75-16,38}{\sqrt{4720,76\left(\frac{1}{4}+\frac{1}{21}\right)}} \\
t=\frac{-4,63}{\sqrt{4720,76(0,25+0,05)}} \\
t=\frac{-4,63}{\sqrt{4720,76(0,3)}} \\
t=\frac{-4,63}{\sqrt{1416,228}}=\frac{-4,63}{37,63}=-0,12
\end{gathered}
$$

\section{Langkah Ketujuh}

Membandingkan ttabel dan thitung. Sedangkan $\mathrm{t}$ tabel diperoleh dari $\mathrm{df}$ (derajat kebebasan) dengan rumus:

$$
\begin{aligned}
\text { df } & =n_{\mathrm{x}}+\mathrm{n}_{\mathrm{y}}-2 \\
& =4+21-2 \\
& =25-2=23
\end{aligned}
$$

Berdasarkan tabel $t$, diketahui bahwa nilai untuk 23 adalah 1,714 maka thitung $\leq t_{\text {tabel}}$, adalah $-0,12 \leq$ 1,714 maka Ho diterima, artinya tidak signifikan.
Nilai untuk $\mathrm{t}_{\text {tabel }} 23$

$t_{\text {hitung }} \leq t_{\text {tabel }}=-0,12 \leq 1,714$

Ternyata, $t_{\text {hitung lebih kecil }}$ dari $t_{\text {tabel }}$, maka terima $\mathrm{H}_{\mathrm{o}}$ dan tolak $\mathrm{H}_{\mathrm{a}}$. Dengan demikian tidak terdapat pengaruh yang positif dan signifikan antara motivasi guru terhadap aktivitas belajar siswa kelas tinggi di Madrasah Ibtidaiyah Pondok Pesantren Al-Rasyid Simpang Jaya Kecamatan Batang Tuaka.

Dari data hasil observasi terhadap variabel $\mathrm{X}$ dapat dianalisa bahwa motivasi guru di Madrasah Ibtidaiyah Pondok Pesantren Al-Rasyid Simpang Jaya Kecamatan Batang Tuaka, mencapai angka $55,95 \%$ dan dikategorikan cukup baik. Karena angka $55,95 \%$ terletak pada interval $41 \%$ $60 \%$.

Dari data hasil observasi terhadap variabel $\mathrm{Y}$ dapat dianalisa bahwa aktivitas belajar siswa kelas tinggi di Madrasah Ibtidaiyah Pondok Pesantren Al-Rasyid Simpang Jaya Kecamatan Batang Tuaka, mencapai angka 49,64\% dan dikategorikan cukup baik. Karena angka $49,64 \%$ terletak pada interval $41 \%$ $-60 \%$.

Dari data melalui observasi terhadap variabel $\mathrm{X}$ dan variabel $\mathrm{Y}$, dapat dianalisa bahwa tidak terdapat pengaruh yang positif dan signifikan antara motivasi guru terhadap aktivitas belajar siswa kelas tinggi di Madrasah Ibtidaiyah Pondok Pesantren Al-Rasyid Simpang Jaya Kecamatan Batang Tuaka, yang ditunjukkan dengan angka -0,12 dan diinterpretasikan sangat rendah. Karena berdasarkan tabel t, nilai untuk 23 adalah 1,714. 
Sehingga $t_{\text {hitung }} \leq t_{\text {tabel }}$, artinya $t_{\text {hitung }} \leq t_{\text {tabel }}=-0,12 \leq 1,714$, maka $\mathrm{H}_{\mathrm{o}}$ diterima, angka $-0,12$ terletak pada daerah penolakan, maka $\mathrm{H}_{\mathrm{a}}$ ditolak dan

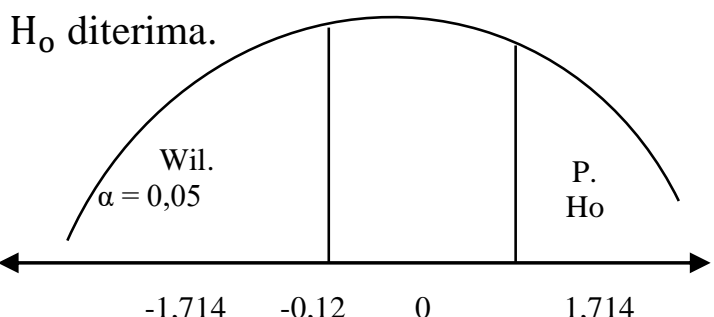

\section{KESIMPULAN}

Berdasarkan analisa data melalui observasi pada penelitian ini dapat disimpulkan bahwa: Motivasi guru di Madrasah Ibtidaiyah Pondok Pesantren Al-Rasyid Simpang Jaya Kecamatan Batang Tuaka, mencapai angka 55,95\% dan dikategorikan cukup baik. Karena angka 55,95\% terletak pada interval $41 \%-60 \%$.

Aktivitas belajar siswa kelas tinggi di Madrasah Ibtidaiyah Pondok Pesantren Al-Rasyid Simpang Jaya Kecamatan Batang Tuaka, mencapai angka 49,64\% dan dikategorikan cukup baik. Karena angka 49,64\% terletak pada interval $41 \%$ - $60 \%$.

Tidak terdapat pengaruh yang positif dan signifikan antara motivasi guru terhadap aktivitas belajar siswa kelas tinggi di Madrasah Ibtidaiyah Pondok Pesantren Al-Rasyid Simpang Jaya Kecamatan Batang Tuaka, yang ditunjukkan dengan angka $-0,12$ dan diinterpretasikan sangat rendah. Karena berdasarkan tabel t, nilai untuk 23 adalah 1,714. Sehingga $t_{\text {hitung }} \leq t_{\text {tabel }}$, artinya $t_{\text {hitung }} \leq t_{\text {tabel }}$ $=-0,12 \leq 1,714$, maka $H_{o}$ diterima, angka $-0,12$ terletak pada daerah penolakan, maka $\mathrm{H}_{a}$ ditolak dan $\mathrm{H}_{\mathrm{o}}$ diterima.

\section{REFERENSI}

Anas Sudijono. (2008). Pengantar Statistik Pendidikan. Jakarta: Raja Grafindo Persada.

Burhan Bungin. (2010). Metodologi penelitian Kualitatif. Jakarta: Raja Grafindo Persada.

Cholid Narbuko dan Abu Ahmad. (2005). Metodologi Penelitian. Jakarta: Bumi Aksara.

Depdikbud. (1990). PP No. 8 tahun 1990 Tentang Pendidikan Dasar. Jakarta: Depdikbud.

Dirto Hadi Susanto. (2007). Kapita Selekta Pendidikan. Yogyakarta: FKIP.

Djiwandono dan Siti Nuryani. (2002). Psikologi Pendidikan. Jakarta: Grasindo Persada.

E. Mulyasa. (2002). Kurikulum Berbasis Kompetensi. Bandung: Rosdakarya.

Gafar Ginandjar. (2007). Kiat Mengatasi Kejenuhan dalam Aktivitas Belajar. Bandung: Prospect.

H. Abu Ahmadi dan Widodo Supriyono. (2004). Psikologi Belajar. Jakarta: Rineka Cipta.

H.M. Musfiqon. (2012). Metodologi Penelitian Pendidikan. Jakarta: Prestasi Pustakaraya.

Iskandar. (2010). Metodologi Penelitian Pendidikan. Jakarta: Gaung Persada Press.

Kunandar. (2008). Guru Profesional Implementasi KTSP dan Sukses dalam Sertifikasi Guru. Jakarta: Raja Grafindo Persada.

M. Sobry Sutikno. (2009). Belajar dan Pembelajaran Upaya Kreatif dalam Mewujudkan Pembelajaran yang Berhasil. Bandung: Prospect.

Nasution. (2000). Berbagai Pendekatan Dalam Proses Belajar dan Mengajar. Jakarta: PT. Bumi Aksara. 
Oemar Hamalik. (2010). Proses Belajar Mengajar. Bandung: Pustaka Martiana.

Pius Abdillah dan Danu Prasetya. (2002). Kamus Bahasa Indonesia. Surabaya: Arkola.

Pupuh Fathurrahman. (2007). Strategi Belajar Mengajar. Bandung: Refika Aditama.

Riduwan. (2002). Skala Pengukuran Variabel-Variabel Penelitian. Bandung: Alfabeta.

(2010). Dasar-Dasar Statistika. Bandung: Alfabeta.

Rohman. (1999). Pendidikan Guru dalam Arus Perubahan; Konvensi pendidikan II. Medan: Purnama.

Sardiman A.M. (2008). Interaksi dan Motivasi Belajar Mengajar. Jakarta: Raja Grafindo Persada.

Sukardi. (2005). Metodologi Penelitian Pendidikan. Jakarta: Bumi Aksara.

Sumadi Suryabrata. (2004). Psikologi Pendidikan. Jakarta: Rajawali Press.

Syaiful Bahri Djamarah. (2006). Strategi Belajar Mengajar. Jakarta: Rineka Cipta.

Tim Reality. (2008). Kamus Bahasa Indonesia. Surabaya: Reality Publisher.

Wasty Soemanto. (1998). Psikologi Pendidikan. Jakarta: Rineka Cipta.

Wina Sanjaya. 2008. Kurikulum dan Pembelajaran, Teori dan Pengembangan KTSP. Jakarta: Prenada Media Group.

Winarno Surakhmad. (2002). Pengantar Interaksi Belajar Mengajar. Bandung: Transifo. 